\title{
FIELD EVAUATION OF SOME INSECTICIDES AGAINST PEAR PSYLLID, CACOPSYLLA PYRICOLA (FOERSTER) (HEMIPTERA: PSYLLOIDEA, PSYLLIDAE) ON PEAR TREES IN ISMAILIYA GOVERNORATE, EGYPT
}

\author{
YOUSSEF, A. S. and SEHAM M. EL-MAHDY
}

Plant Protection Research Institute, ARC, Dokki, Giza, Egypt

(Manuscript received 28 June 2015)

\begin{abstract}
A field experiment was carried out during April, 2014 in pear orchard at Ismailiya Governorate to evaluate the efficiency of four insecticides against the pear psyllid, Cacopsylla pyricola (Foerster) (Hemiptera: Psylloidea, Psyllidae) on pear trees. Obtained results showed that, the tested insecticides were highly effective on the insect population. The statistical analysis of nymphal reduction population showed that, Acetamiprid was the most efficient compound (97.2\%) followed by Phosmet (97.1\%), Mineral oil (93.0\%) and Pyriproxyfen (92.8\%). Also, Acetamiprid was the highest effective insecticides on the adult population showing $(96.7 \%)$ followed by Pyriproxyfen $(95.6 \%)$ then Phosmet $(94.8 \%)$ and Mineral oil $(92.9 \%)$, respectively. The reduction of the insect population reached its maximum by the $5^{\text {th }}$ week, by more than $(97.0 \%)$ for the nymph and adult populations. The obtained results revealed that, the post-spraying must be continue 5 weeks after application to reach the efficiency of the evaluated insecticides for control the pear psyllid, C. pyricola on pear trees.
\end{abstract}

\section{INTRODUCTION}

The pear psyllid, Cacopsylla pyricola (Foerster) was recorded on pear trees for the first time at El-Arish, North Sinai and Ismailiya Governorates, Egypt (Ahmed, 2007). The damage may be exacerbated by a sooty mold fungus that colonizes honeydew and also marks fruit (Burts, 1970); at high densities of insect, the fungus may additionally cause a reduction in photosynthesis. These symptoms have collectively been termed psylla shock, and are caused by a toxin in the saliva of feeding nymphs. Symptoms of the injury can be similar in appearance to those associated with pear decline disease (Beers, et al. 1993). During the last few years this species became a key pest on pear trees in most of growing orchards in Egypt.

Field observations and ecological studies showed that the females of this pest began to be active from late March. Adult females began to deposit eggs on terminal buds during this period. The females were preferred base of buds and new leaves to deposit eggs. 
No review of literature about control measures were recorded against pear psyllid, C. pyricola until now in Egypt.

The present work was carried out to evaluate the efficiency of four insecticidal formulations against $C$. pyricola to protect pear trees from the damages caused by this pest.

\section{MATERIALS AND METHODS}

Pear orchard about three feddans in Ismailiya Governorate was chosen for experimental purposes. Pear trees, Pyrus communis var. Le-Conte about 15 years old. Forty five trees of same size, height and heavily infested with pear psyllid, C. pyricola were selected for experimental purposes. The experimental design was Randomized Complete Block (RCB). The selected trees were distributed in three blocks; each block (15 trees) was divided into 5 plots ( 3 trees/ plot). The experimental insecticides were randomly distributed in each block and replicated three times in three blocks, while the fifth plot in three blocks was left as control index. The tested compounds with their commercial and common names as well as rate of application are given in Table (1).

Table 1. The four evaluated insecticides with their formulations, common names and rates of application.

\begin{tabular}{|c|c|c|c|}
\hline Common name & Formulation-\% a.i & Pesticide group & Rate of application \\
\hline 1.Pyriproxyfen & Admiral $10 \% \mathrm{EC}$ & $\begin{array}{c}\text { Juvenile Hormone } \\
\text { mimic }(\mathrm{JHm})\end{array}$ & $50 \mathrm{ml} / 100$ liter water \\
\hline 2. Acetamiprid & Mospilan $20 \% \mathrm{SP}$ & Neonicotinoid & $30 \mathrm{gram} / 100$ liter water \\
\hline 3. Phosmet & Imidan 50\% WP & Organophosphorous & $100 \mathrm{gram} / 100$ liter water \\
\hline 4. Mineral oil & Star oil 98\% EC & Mineral oil & 1.5 liter $/ 100$ liter water \\
\hline
\end{tabular}

Spray application was conducted during April, 2014 by using motor sprayer 1.5 hrs. 150 liters tank at pressure 100 pounds on one square inch. Spraying was applied manually to secure complete coverage of all parts of pear trees.

The pre-spraying samples were picked up at random from each replicate before spraying application with rate of 10 twigs $(20 \mathrm{~cm}$ long) /sample whereas the postspraying samples were taken after first, second, third, fourth and fifth weeks intervals. These samples were kept in special plastic boxes and transferred to laboratory for counting procedures by aid of stereoscopic microscope. The reduction percentages of nymphs and adults were calculated according to equation of Henderson and Tilton (1955). The results were subjected to statistical analysis using ANOVA after transferred percentages of mortality to arc-sine, when "F" value was significant LSD values were calculated. 


\section{RESULTS AND DISCUSSION}

Data in Table (2) showed the reduction percentages of nymphs and adult's population of $C$. pyricola as well as the evaluated insecticides after $1^{\text {st }}, 2^{\text {nd }}, 3^{\text {rd }}, 4^{\text {th }}$ and $5^{\text {th }}$ weeks, respectively. Results revealed that the reduction percentages of the tested insecticides on nymphal population were varied after one week of application. The highest effective compounds were Acetamiprid (94.5\%) while; the least effective compounds were Mineral oil (95.6\%) and Pyriproxyfen (95.3\%), respectively. On the other hand, the evaluated insecticides showed the same trend on the adult population. The highest effective compound after one week of application was Acetamiprid (93.1\%), while the lowest compounds were Mineral oil (86.9\%). Statistical analysis showed that, the tested insecticides were highly significant effect on reduction percentages of the nymphal population ("F" value $=106.1$ ). The highest effective compounds were Acetamiprid In the $1^{\text {st }}$ rank (97.2\%) and Phosmet, followed by Mineral oil $(93.0 \%)$ in the $2^{\text {nd }}$ rank while, Pyriproxyfen $(92.8 \%)$ came in the $3^{\text {rd }}$ rank, respectively. Also, results of statistical analysis showed highly significant effect on the adult population ( $F$ value $=85.2$ ). The highest effective insecticides was Acetamiprid $(96.7 \%)$ came in the $1^{\text {st }}$ rank followed by Pyriproxyfen came in the $2^{\text {nd }}$ rank $(95.6 \%)$ while, Phosmet came in the $3^{\text {rd }}$ rank $(94.8 \%)$ and Mineral oil came in the last one (92.9\%).

Data in Table (2) and Figs. (1\&2) showed that, reduction percentages of nymphs and adults populations were varied in the $4^{\text {th }}$ week of application.

The afore-mentioned results showed that, the tested insecticides were highly effective on the insect population and the real effect appeared after fifth weeks of application. So, the present work proved that, the tested compounds were more sufficient as control measures for the pear psyllid, C. pyricola under field conditions.

These results are in harmony with those obtained by Westigard et al. (1980) and Zwick \& Westigard (1978) stated that using mineral oil on pear trees delays in oviposition. Horton and Broers (1997), Hilton and Westigard (1994) and Horton (1996) mentioned that mineral oil delayed dormant or cluster bud application of insect growth regulator but appears to have little toxicity against the adults. 
Table 2. Reduction percentage of C. pyricola population after application with four insecticides on pear trees in Ismailiya Governorate during April, 2014 with results of statistical analysis.

\begin{tabular}{|c|c|c|c|c|c|c|c|c|c|c|c|c|}
\hline \multirow{4}{*}{ Insecticides } & \multicolumn{10}{|c|}{ Reduction percentages } & & \\
\hline & \multicolumn{2}{|c|}{ First week } & \multicolumn{2}{|c|}{ Second week } & \multicolumn{2}{|c|}{ Third week } & \multicolumn{2}{|c|}{ Fourth week } & \multicolumn{2}{|c|}{ Fifth week } & \multicolumn{2}{|c|}{$\begin{array}{c}\text { Reduction percentage } \\
\text { of population }\end{array}$} \\
\hline & \multicolumn{2}{|c|}{$02 / 04 / 2014$} & \multicolumn{2}{|c|}{$18 / 04 / 2014$} & \multicolumn{2}{|c|}{$04 / 05 / 2014$} & \multicolumn{2}{|c|}{$20 / 05 / 2014$} & \multicolumn{2}{|c|}{$05 / 06 / 2014$} & & \\
\hline & Nymph & Adult & Nymph & Adult & Nymph & Adult & Nymph & Adult & Nymph & Adult & Nymph & Adult \\
\hline 1 .Pyriproxyfen & $85.3 \%$ & $88.7 \%$ & $86.9 \%$ & $92.0 \%$ & $94.3 \%$ & $98.3 \%$ & $98.2 \%$ & $99.0 \%$ & $99.3 \%$ & $100 \%$ & $92.8 \% \mathrm{c}$ & $95.6 \% \mathrm{~b}$ \\
\hline 2. Acetamiprid & $94.5 \%$ & $93.1 \%$ & $96.2 \%$ & $95.6 \%$ & $97.6 \%$ & $97.2 \%$ & $98.6 \%$ & $98.5 \%$ & $98.9 \%$ & $98.9 \%$ & $97.2 \%$ a & $96.7 \%$ a \\
\hline 3. Phosmet & $92.8 \%$ & $88.4 \%$ & $96.2 \%$ & $90.4 \%$ & $98.1 \%$ & $96.9 \%$ & $98.9 \%$ & $98.9 \%$ & $99.5 \%$ & $99.2 \%$ & $97.1 \%$ a & $94.8 \% \mathrm{c}$ \\
\hline 4. Mineral oil & $85.6 \%$ & $86.9 \%$ & $88.7 \%$ & $89.2 \%$ & $95.4 \%$ & $94.6 \%$ & $96.9 \%$ & $96.7 \%$ & $97.9 \%$ & $97.0 \%$ & $93.0 \% \mathrm{~b}$ & $92.9 \% \mathrm{~d}$ \\
\hline \multicolumn{11}{|c|}{ "F" value between treatments: } & "*106.1 & "85.2 \\
\hline \multicolumn{11}{|c|}{ LSD at ${ }_{0.05}$ level : } & 0.15 & 0.61 \\
\hline
\end{tabular}

\section{Note :}

Reduction percentages were transferred to arc sine values before conducting analysis of variance.

Means in the same column not followed by the same letter is significantly different $(P<0.05)$ using LSD test in MSTATC computer Program. 


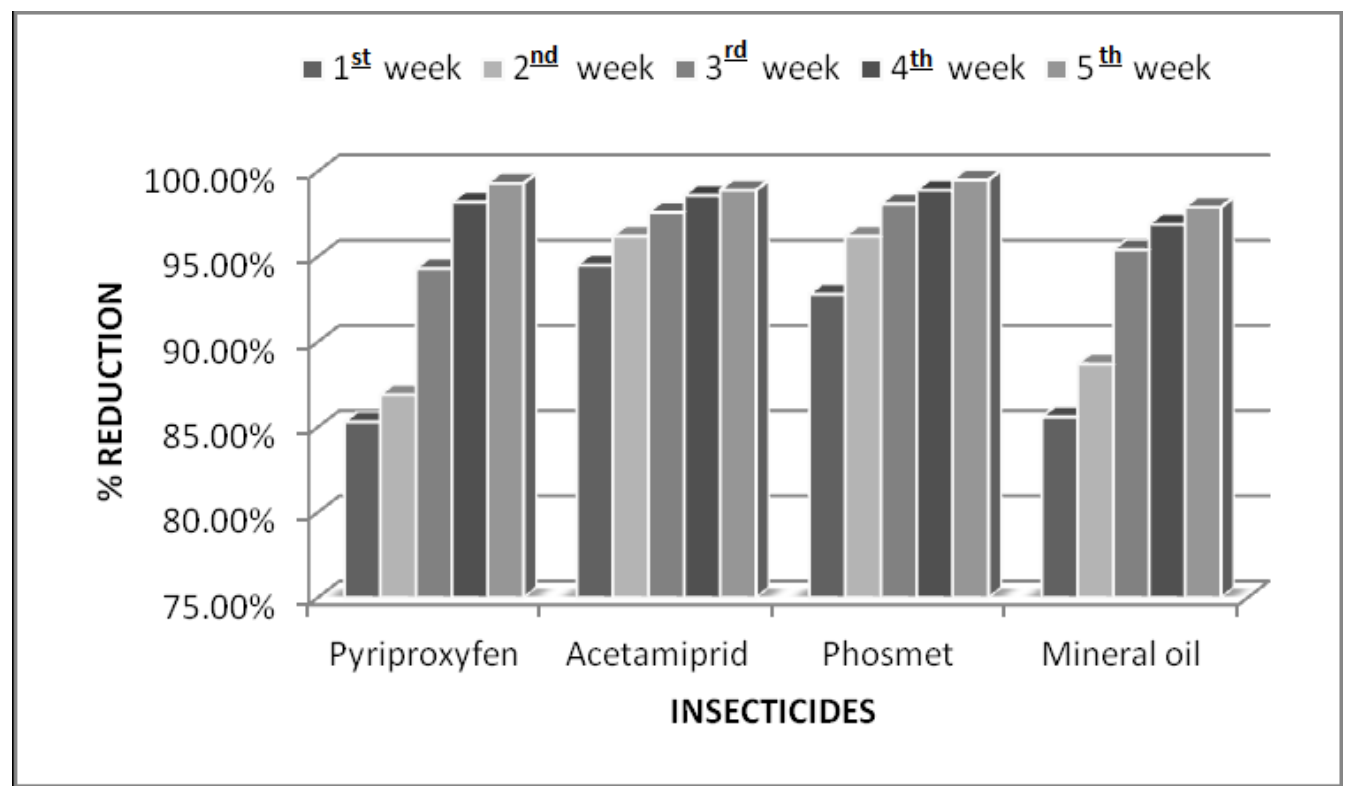

Fig. 1. Reduction percentages of nymphal population of the pear psyllid, C. pyricola after spraying with four insecticides in Ismailiya Governorate during April, 2014.

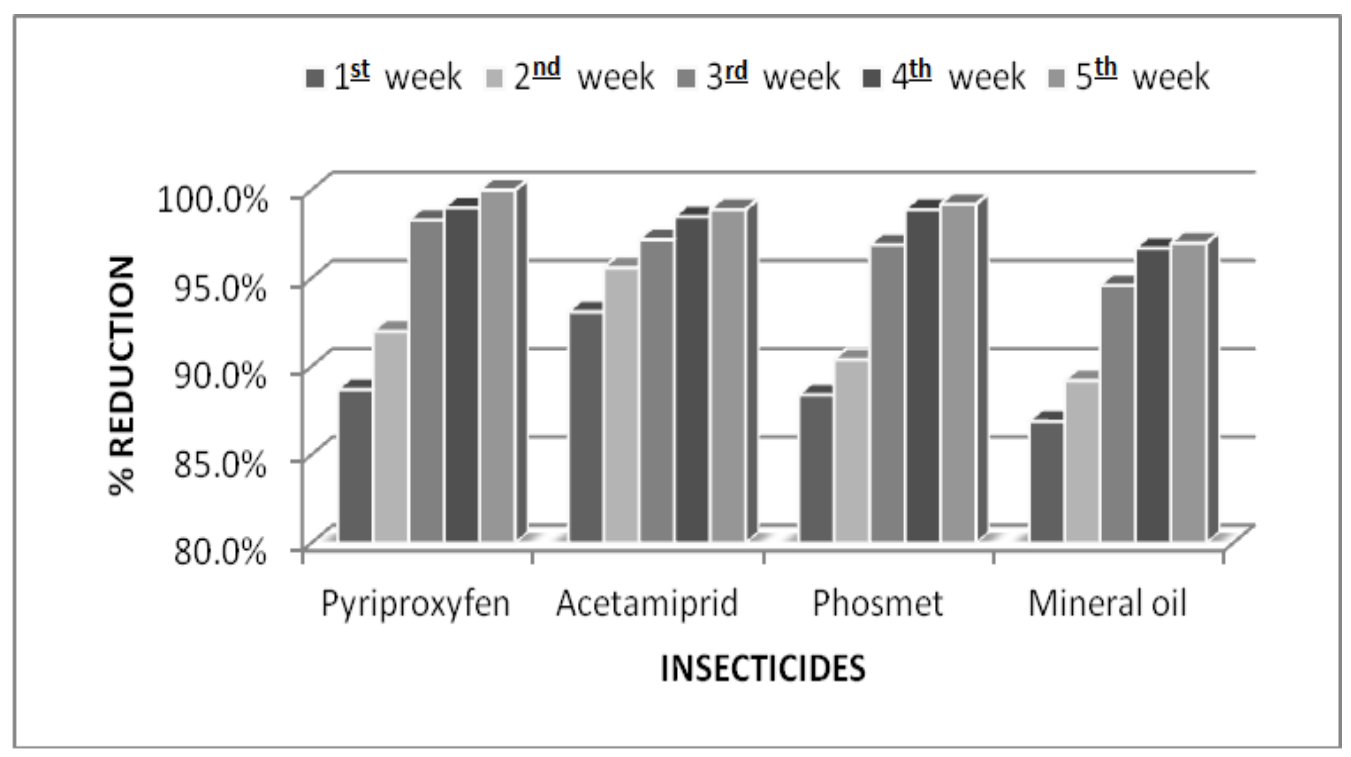

Fig. 2. Reduction percentages of adult population of the pear psyllid, C. pyricola after spraying with four insecticides in Ismailiya Governorate during April, 2014. 


\section{REFERENCES}

1. Ahmed, S. A. 2007. Description of the pear psyllid, Cacopsylla pyricola (Foerster) (Hemiptera: Psyllidae), a new record in pear orchards in North Sinai and Ismailiya Governorates, Egypt. Egyptian J. Biol. Pest Control Vol. 17 No. 1/2 pp. 159 -160.

2. Burts, E.C. 1970. The pear psylla in Central Washington. Washington State University, Washington Agricultural Experiment Station Circular 516, WA: Pullman, $13 \mathrm{pp}$.

3. Beers, E.H., Brunner, J.F., Willet, M.J. and Warner, G.M. 1993. Orchard Pest Management: A Resource Book for the Pacific Northwest. Yakima, WA: Good Fruit Grower.

4. Henderson, C. F. and E. W. Tilton. 1955. Test with acaricides against the brown wheat mite. J. Econ. Entomol. 48: 157-161.

5. Hilton, R. and Westigard, P. 1994. Pre-bloom evaluations of Fenoxycarb and Danitol for pear psylla control. Proc. West. Orch. Pest and Disease Mgmt. Conf. 68, p. 73.

6. Horton, D.R. 1996. Timing of pre-bloom 'Comply' sprays and effects on first generation pear psylla. Good Fruit Grower 47(4), 50-1.

7. Horton, D.R. and Broers, D.A. 1997. Mortality in eggs of pear psylla (Homoptera: Psyllidae) caused by Fenoxycarb in combination with a water drench. J. Entomol. Soc. Brit. Col. 94 (Dec.), 31-4.

8. Westigard, P.H., Lombard, P.B., Allen, R.B and Strang, J.G. 1980. Pear psylla: population suppression through host plant modification using Daminozide. Environ. Entomol. 9, 275-7.

9. Zwick, R.W. and Westigard, P.H. 1978. Pre-bloom petroleum oil applications for delaying pear psylla (Homoptera: Psyllidae) oviposition. Can. Entomol. 110, 22536. 


\section{التقييم الحقلى لبعض المبيدات الحشرية فى مكافحة حشرة Cacopsylla pyricola}

(Hemiptera: Psylloidea: Psyllidae)

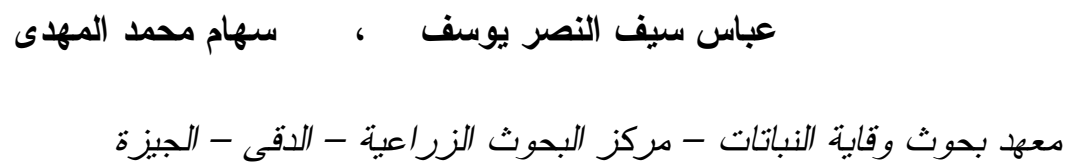

أجريت تجربة حقلية فى مزرعة خاصة بمحافظة الإسماعيلية فى 10 أبريل ع ا ب؟،

وذللك لتقييم كفاءة أربعة مجمو عات مختلفة من المبيدات لمكافحة حشرة Cacopsylla pyricola

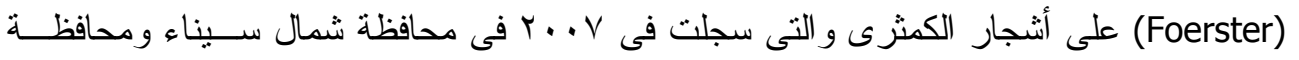
الأسماعيلية وسببت أضرار فى مزارع الكمثرى ، وتهدف الدراسة الحالية حماية أثجار الكمثرى من الضرر الناتج عن الإصابة بهذه الآفة.

أوضحت النتائج كفاءة المبيدات المختبرة فى مكافحة الحوريات ، كانت أكثتـر المبيـــات

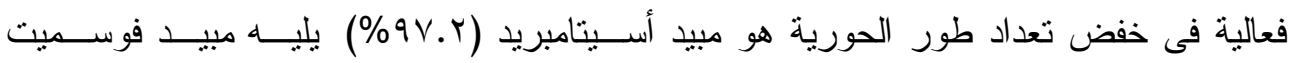

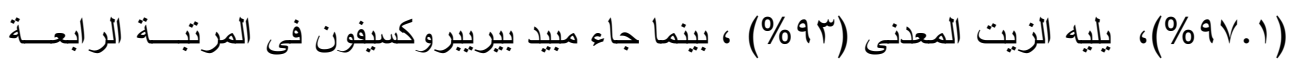

أوضحت النتائج كفاءة المبيدات المختبرة فى خفض تعداد الحشرة الكاملة حيث جاء مبيـــ

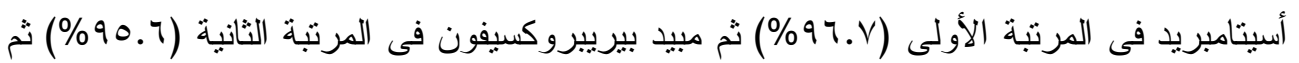
مبيد فوسميت فى المرتبة الثالثة (90.7\%) وجاء الزيــت المعـدنى فـى المرنبــة الأخيـرة .$(\% 9 r .9)$

أوضحت النتائج أن نسب الخفض فى تعداد طورى الحورية و الحشرة الكاملة وصل أقصاه

$$
\text { فى الأسبوع الخامس بعد الرش (أكثر من \9\%). }
$$

